\title{
The Importance of Ecological Studies as a Basis for Land-use Planning*
}

\author{
Stanley A. Cain, Ph.D. (Chicago) \\ Charles Lathrop Pack Professor of Conservation in the University of Michigan; Assistant Secretary for Fish, Wildlife and \\ Parks, United States Department of the Interior, Interior Building, Washington, D.C. 20240, U.S.A.
}

\begin{abstract}
SUMMARY
However valuable and indispensable the results of the specialized sciences, it is maintained that they must be unified by ecology-the science of interrelations - if natural resources are to be wisely managed and an environment of quality maintained or restored. Furthermore, the problems of resource use are not amenable to solution by the natural sciences alone, for each has economic, political, and other social parameters.
\end{abstract}

I believe that we have long had an imbalance in our scientific effort. Biology has made its advances, of course; these are well known in biochemistry, biophysics, and genetics, and through their pay-off in medicine and health. But it is the 'hard sciences' in support of physical technology that have done more to change the modern world and its industrial processes.

Our concentrated attention to physical technology, with its quick and profitable pay-offs, has worked up to a point. But we are now appreciating that our relative neglect of systems in nature, especially the vastly more complicated systems of biology and culture, has given us the urgent critical problems of our time.

It is not reasonable to criticize past actions on a basis of present knowledge, although we may have ample cause to regret them because it is so costly to correct our mistakes. Today it is unreasonable not to manage our land resources so as to avoid destructive soil erosion, our water resources so as to curb destructive flooding, our forests and grasslands so as to maintain their natural productivity, and our fish and wildlife so that they will continue to supply us and give us

* Based originally on the Author's testimony before the Subcommittee on Science, Research, and Development of the Committee on Science and Astronautics of the House of Representatives of the United States of America, 12 July, 1967, and on his remarks at the I.U.C.N. etc. Conferencia Latinoamericana sobre Conservacion de Recursos Naturales Renovable, 27 March-2 April, 1968, at San Carlos de Bariloche, Rio Negro, Argentina. pleasure. The knowledge that permits sound management of natural resources stems from all of the natural sciences - from botany and zoology, with their many sub-divisions such as physiology, nutrition, genetics, and pathology; from chemistry and physics, especially as they bridge the life sciences through biochemistry and biophysics; from geology, soils, climatology, and meteorology, as related to living natural resources.

\section{ECOLOGY THE SYNTHESIS}

Indispensable as they are, these separate scientific disciplines cannot yield an ultimate understanding of nature because they are essentially analytical and too compartmentalized. They must be made to work together. They must be interrelated as their objects of study are in nature. What is being appreciated gradually is that ecology is the science which is capable of such synthesis, because its attention is not directed at things, processes, and conditions as though they existed in isolation but rather at the interrelations among them.

I am convinced that ecology - or perhaps better, the ecological way of looking at nature - is beginning to provide the means of synthesizing the sciences and of finding out how nature really works.

We are beginning to appreciate that the atmosphere functions as a system, and that the hydrosphere, the soil, and biological communities, do so also. But these are really no more than sub-systems, complex as they are, and they interact to produce ecosystems which may be defined as organized plant-animal communities together with their inseparable physical environments.

While $1 \mathrm{am}$ convinced that ecology is the science that can weld together the other natural sciences in the use of natural resources, it seems equally clear that biological ecology alone cannot provide the basis for land-use planning. Planning is done by people. This means that sociology, cultural anthropology, economics, political science, and law, must also make 33 
their technical contributions to land-use planning. Because the emphasis is still on interrelations, some of us would broaden ecology to include these inputs that enhance the understanding of human ecosystems.

\section{MANKIND'S COSTLY MISTAKES}

History is full of costly mistakes and some fiascos that would not have occurred had there been adequate ecological information or even a feeling for ecological relationships in nature. Here are a few examples that are well known:

(1) Around the turn of the century in the United States, after we had cut over most areas of Eastern and Great Lakes timber and inroads were being made in the Gulf States and the West, there was a surge of reforestation programmes for fear that we would run out of timber. Many of these plantations were complete failures because of the use of ill-adapted species or strains from climates quite different from those in the areas of the new plantings. Even as we developed more sense about this, it took a few more decades to realize that most conifers grow better with intermingled plantings of broadleaf species, because of the effect of the latter in maintaining mineral balance and structure in the soil.

(2) In the early post-war years, Great Britain undertook an extensive groundnut (peanut) programme in East Africa and lost some millions of pounds because the interrelations of savanna vegetation, savanna climate, and savanna soils, were not understood. The planners, with a proper feeling for the nutritional need for more oil and protein among native peoples, had ground prepared, peanuts planted - and hearts broken when the dry-season soils became like concrete.

(3) Again in the early post-war years, UNESCO started a Hylean Amazonian programme that was to develop a new breadbasket for the world's hungry people. There were international political troubles, but a central cause of failure was an inadequate understanding of tropical rain-forest ecology, including lateritic soils. Something similar happened to Ford's rubber plantations and other efforts at monoculture in an area of the world's most complex natural vegetation.

(4) Much of the devastation and deterioration of soils in East Africa is due to dependence on cattle. Dr Fraser Darling and others have pointed out that more useful animal flesh suitable for human consumption is laid down on the several species of native ungulates than on domestic cattle, and this is done without loss of range productivity. Something similar can be done about much of our treatment of the arid and semi-arid Western United States, where overgrazing by cattle and sheep has seriously depleted range productivity. We, too, have participated, and even continue to participate, in what has been called the Saharaization of the land.

(5) A pesticide programme in Nova Scotia was embarked upon to control Spruce Budworm. The Budworm was inadequately controlled, other insects developed damaging populations, valuable insecteating birds were killed, and Salmon almost disappeared from the streams.

(6) In Pakistan, in the U.S. Southwest, and in many other arid and semi-arid places, faulty irrigation practices have ruined the soil for crop production by accumulation of salts at the surface and by the development of shallow hardpans.

(7) In parts of southern Florida the combination of over-drainage and over-draft of aquifers for irrigated agriculture has destroyed the productivity of the soil, in some cases in only a few years' time.

As I have said, it is not entirely fair to judge the acts of history in the light of subsequent knowledge, but it is fair to say that the checks and balances of nature never seem to have caused enough concern. The attractions of immediate profit, and the stultifying influence of traditional practices, cause many persons to think only about immediate conditions, forgetting or ignoring possible longer-term consequences of their actions.

\section{DEVASTATING UNFORESEEN CONSEQUENCES}

We are still pursuing too many essentially singlepurpose programmes, and so running the risk of failure - not necessarily failure to accomplish the narrow objective, but failure to anticipate the consequences of our actions. These consequences, which are often unexplored side-effects, are ignored until they bear down upon us with intolerable changes in the environment. In some cases the cost of these changes may far exceed the direct benefits of a project. The following examples will suffice to illustrate these points:

(a) Most of our pollution problems of air, water, and soil, have arisen because we have come only late to consider the effects of emitted gases, solid wastes, and organic trash, on the environment on which our very lives depend. Clever engineering went into everything but exhaust trash of internal combustion 
engines. Clever engineering goes into paper-making and the manufacture of thousands of industrial products - and the poisonous effluents pour into streams, lakes, and seas. Only now, after decades of unconcern, are we mounting an intensive programme to handle human wastes by means other than pollution dilution. We are just now beginning to be given cost-estimates for the correction of our oversights, and the tag is in the thousands of millions of dollars in the United States alone. In these terribly important matters, environmental science is still in its infancy.

(b) We have spent millions of dollars on research and control of Lamprey in the Great Lakes, and are now spending more millions to re-establish Lake Trout and Whitefish and control Alewife. The Lamprey and Alewife came into the Great Lakes from the sea, using canals which were constructed with no thought of their biological consequences.

(c) Today we are financing a Commission that is studying a sea-level canal to be built somewhere in Panama or northern South America. There are two aspects of thinking about this, at least up to now, that suggest an almost complete ecological ignorance. One is the biological consequences of joining the Caribbean Sea and the Pacific Ocean that have been separated for some 25 million years. The other is the possible, I would say probable, consequences of excavating the canal by nuclear explosions -- consequences on Man and Nature. Any problem of radioactive isotopes is by no means a local one. Such materials pass along the food-chains. Atlantic Tuna have recently been found to cross from one side of the Atlantic to the other. Some migratory birds move between the area and the Arctic. Crustacea accumulate these substances, as they do pesticides, and pass them along the foodchains.

(d) High dams have been built without consideration of the warming of downstream waters and its effect on valuable fish resources, and sometimes without provision for passage of anadromous species.

(e) As more and more nuclear power-plants are being constructed we are only belatedly, even in these times of scientific sophistication, beginning to design them for avoidance of heat pollution.

(f) The physical destruction of estuaries by dredging, excavating, and filling, has been continuing with little thought for the ecology of these complicated natural areas and their value for commercial and sport fisheries, wildlife, natural beauty, and recreation.

(g) We are now well embarked upon a programme of research and pilot experimentation with weather modification. It is an attractive and challenging idea, and one that promises to provide supplementary water in places where it is needed. But up to now there has been no significant attention paid to consequences of weather modification if it should become operationally successful. It is my guess that the necessary studies on the biological, economic, and legal consequences of weather modification would be as expensive as the research to accomplish it, which now is running at the rate of about five million dollars a year in the United States alone. Moreover, monitoring the modification could be a continuing cost as great as that of seeding the clouds. If precipitation were to be augmented by 10 per cent, or perhaps by $15-20$ per cent, ecological systems could be shifted hundreds of miles under certain circumstances, and the economy of entire regions could be disoriented.

\section{SOME SUCCESSFUL APPLICATIONS}

The record is not all bad. Ecological knowledge has been put to work in many cases with great success, and the pay-off has been important. Better fundamental knowledge of biological systems to serve as the basis on which applied findings may be derived should constitute a valuable return from the substantial investment in the current International Biological Programme. Some instances are, or should be:

(1) Knowledge of freshwater systems is being put to work in fish-pond developments, for instance, in the Middle West and South of the United States, which produce as much as a ton of fish per acre annually. And in rice-growing areas fish are raised with paddy (rice), or with rotated soybeans and paddy.

(2) Aquaculture is being extended to salt and brackish waters in the cultivation and farming of oysters and shrimp.

(3) Reservoirs and lakes are being stocked with carefully selected organisms to fill out a productive food-chain.

(4) Forest and range units are becoming more productive of a wide variety of goods and services, because their management is firmly based on knowledge of plant and animal ecology.

(5) Systematic, long-term research into the central Pacific Ocean as a complete environmental system has led to the discovery of such things as the equatorial undercurrent, factors explaining distribution and abundance of Tuna, and prediction of Skipjack catch on the basis of seasonal warming and location of water masses.

(6) The programme of our United States Soil 
Conservation Service, designed in the 1930s to help correct the mistakes of our past soil and water mismanagement, has matured into a land capability system that helps allocate each acre to its highest sustainable use; this might be emulated in other countries to their great advantage.

(7) Comparative agrobiology and agroclimatology are guiding land use developments around the world, or at least have the capacity to do so.

(8) Identification and study of planktonic eggs and larvae in the California ocean-current system have led to discovery and developement of Pacific Hake resources to support an expanding fishing enterprise off the State of Washington.

(9) Many massive health programmes are founded on detailed ecological knowledge of vector roles and their niches in the biological-environmental systems of nature. Disease problems in every part of the world, from rain forest to desert to tundra and high mountains, have caused medical researchers to look closely at the natural and agricultural communities in which people live.

\section{THE WORLD'S FUNDAMENTAL DILEMMA}

In conclusion I wish to recognize a fundamental dilemma that faces people in many parts of the world. Some have called it 'land hunger', because there seems not to be enough arable land on which food and other products can be produced for hungry and ever-morenumerous millions of people. Others feel that limited natural resources are not generally the basic problem. Instead, they say, the problem is our failure to organize matters politically and economically - to put to work the science and technology that already exist-so that productivity of living resources can be enhanced, and mineral and other resources can be made usable, without needless destruction of other values.

When human needs are so great, how can the planner say to the small farmer who has no other land for his family's subsistence, 'Don't grow corn on that hillside, the slope is so great.'

The dilemma, as Malthus said long ago, is that it is easier for human population to double and double again in a few brief decades than it is for production increases to keep pace. For nearly a century and a half it seemed that Malthus' thesis was incorrect, because technology in some few parts of the world was producing an abundance that mankind had never before known. But today in many parts of the world what we now call the 'population explosion' is causing hundreds of millions of people to suffer the consequences of the Malthusian dilemma.
Ecological land-use planning will help to solve the dilemma, but that alone is inadequate. The human ecosystem is not only the web of interrelations between Man and natural resources; it is the much more complex web of interactions that include all of the societal factors which affect what we do and how we do it.

\section{The Japanese Crested Ibis or Toki}

Although this handsome species, Nipponia nippon, was formerly plentiful throughout Japan, the numbers became so reduced that in 1934 the Government designated it a 'National Natural Monument' and the forests in the vicinity of its breeding area were strictly protected - until they were destroyed during and after World War II. With this destruction the numbers of Nipponia nippon further diminished until a special protective measure was proclaimed in 1960, when there were five birds on Sado Island and probably a similar number on Noto Peninsula. Since then the former population has doubled but the latter has become reduced to a single individual, so that the over-all situation has scarcely improved.

So much for the eastern part of the range of the Toki; the status of the species on the mainland of Korea and China is less clear, though it apparently still exists there in the wild state. The accompanying drawing has been generously contributed by our Consulting Editor Peter Scott.

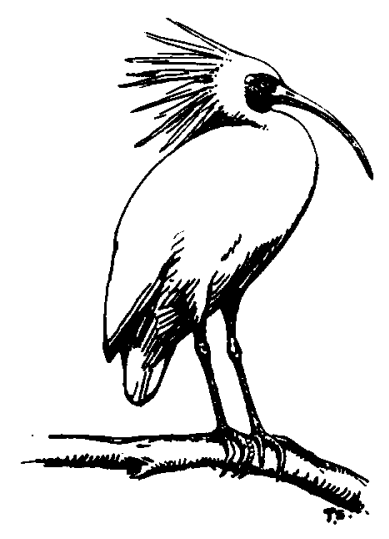

The Japanese National Section of the International Council for Bird Preservation hopes to increase the numbers of Nipponia nippon through (1) providing a feeding-basin in the marshy land, close to the forests, where the adult birds usually feed each day; (2) rearing plentiful Loaches, a favourite food of this Ibis, completely free from pesticides, so that the birds would be provided with innocuous food even in the snow-bound winter season; (3) providing a wire-netting fence around the feeding-basin to keep out possible predators such as Badgers and Japanese Mink; and (4) building a flying-cage in part of the feeding-basin in the hope of propagating more lbises. It is also hoped to build a house for the caretaker of the reserved area and to purchase surrounding forest lands. (Main source X Bulletin of I.C.B.P., 1967.) 